\title{
Adult-onset idiopathic Type I or ketosis-prone Type II diabetes: evidence to revisit diabetes classification
}

\author{
E.Sobngwi, J.-F. Gautier \\ Department of Diabetes and Endocrinology, St-Louis Hospital, Paris, France
}

Uniform criteria for the diagnosis and classification of diabetes have been defined and improved over the past two decades to allow for a consistent epidemiological and clinical approach of this syndrome across the world. However, precise typing of some unusual presentations remains difficult.

At present the most often reported atypical presentation is one that is characterised by acute onset with ketosis and possible subsequent long-term nearnormoglycaemic remission $[1,2]$. This atypical presentation with phasic insulin dependence had been referred to, or described, in African literature in the past four decades [3-6]. Although it is mostly found in adult populations of African ancestry, there are some reports of such presentations in other ethnic groups [7]. The main features are the onset compatible with classic Type I (insulin-dependent) diabetes mellitus with deficient insulin secretory response to glucose, the absence of pancreatic beta-cell autoimmunity, and possible subsequent near-normoglycaemic control under diet and exercise with or without oral hypoglycaemic drugs [8-10]. The American Diabetes Association (ADA) classified this subtype as "idiopathic Type I diabetes" or "Type IB" [11]. The WHO consultation identified two forms of "idiopathic Type I diabetes", the first being similar to autoimmune Type I with the exception of beta-cell autoimmunity, and the second referring to diabetes with phasic insulin dependence [12]. However, we believe on the basis of available evidence that classification of this atypical diabetes usually found in African patients should be revisited.

Received: 6 September 2001 and in revised form: 29 October 2001

Corresponding author: J.-F. Gautier, Department of Diabetes and Endocrinology, St-Louis Hospital, Paris, 1, avenue Claude Vellefaux, 75475 Paris Cedex 10, France, e-mail: j-fgautier@ wanadoo.fr
Patients with this atypical diabetes seldom have the characteristics usually associated with classic Type I diabetes (Table 1). Mean age at diagnosis varies from 35 to 46 years and is therefore usually higher than generally reported in classic Type I diabetes. Latent autoimmune diabetes is not plausible since late appearance of islet-cell autoimmunity has not been reported. Obesity, which is an exceptional finding in classic Type I diabetes, is found in up to $56 \%$ of the cohorts of patients with this atypical presentation [8] and mean BMI varies between 26 and $37 \mathrm{~kg} / \mathrm{m}^{2}$ [1, 2, $9,10]$.

In addition, Type I diabetes is characterised by beta-cell destruction according to both ADA and WHO texts $[11,12]$. In the subtype we are referring to, no evidence of autoimmune destruction of beta cells has been reported. There is, however, a blunted insulin response to glucose that partially recovers with normoglycaemic control [2]. Moreover, the insulin secretory response to glucagon is partially preserved [9]. Therefore, beta-cell destruction, if any, would not explain the initial lack of insulin response to glucose since this phenomenon is partially reversible.

In contrast, several features of Type II (insulin-dependent) diabetes mellitus are almost constantly found in the patients with atypical ketosis-prone diabetes (Table 1). Age at onset is comparable to that of Type II diabetic patients of African origin. Indeed, age at onset of Type II diabetes is lower in African populations compared to Caucasians [13]. The proportion of overweight and obese patients is similar to that of Type II cohorts of similar ethnic and socioeconomic background. Family history of Type II diabetes approaches $90 \%$ and would tend to suggest that these patients could also have Type II diabetes, since there is a stronger familial predisposition in Type II compared with Type I diabetes.

Type II diabetes is characterised by an association of variable degrees of insulin resistance and insulin 
Table 1. Clinical and biological characteristics of patients with atypical diabetes

\begin{tabular}{|c|c|c|c|c|}
\hline & Banerji et al. 1994 [1] & Umpierrez et al. 1995 [2] & Banerji et al. 1996 [10] & Umpierrez et al. 1999 [8] \\
\hline$n$ & 21 & 35 & 79 & 77 \\
\hline $\begin{array}{l}\text { Age at presentation } \\
\text { (years) }\end{array}$ & $45 \pm 9$ & $40 \pm 2$ & $45 \pm 10$ & $40 \pm 2$ \\
\hline $\begin{array}{l}\text { Family history of } \\
\text { diabetes }(\%)\end{array}$ & 67 & 84 & 78 & 82 \\
\hline $\begin{array}{l}\text { BMI at presentation } \\
\left(\mathrm{kg} / \mathrm{m}^{2}\right)\end{array}$ & $20.2-33.8$ (range) & $\begin{array}{l}157 \pm 6 \% \text { of ideal body } \\
\text { weight }\end{array}$ & $\begin{array}{l}28.8 \pm 3.7 \\
(\text { mean and SD) }\end{array}$ & $37 \pm 1$ \\
\hline $\begin{array}{l}\text { Anti GAD or ICA } \\
\text { positive }\end{array}$ & 1/21 GAD; 0 ICA & $0 \%$ & 1/70 GAD; 0 ICA & $\begin{array}{l}13 \% \text { ICA, } 3 \% \text { GAD, } \\
3 \% \text { IAA }\end{array}$ \\
\hline Insulin secretion & $\begin{array}{l}77 \% \text { of C-peptide } \\
\text { response to oral glucose } \\
\text { compared to a non dia- } \\
\text { betic control population }\end{array}$ & $\begin{array}{l}6(\mathrm{I}) \text { to } 20(\mathrm{R}) \% \text { of } \\
\text { C-peptide response to } \\
\text { IVGTT compared to } \\
\text { obese non diabetic } \\
\text { controls }^{\mathrm{a}}\end{array}$ & $\begin{array}{l}57-70 \% \text { of insulin area } \\
\text { minus basal in response } \\
\text { to oral glucose compar- } \\
\text { ed to a non diabetic } \\
\text { control population }\end{array}$ & $\begin{array}{l}59 \% \text { of C-peptide response } \\
\text { to glucagon compared to } \\
\text { non diabetic controls }\end{array}$ \\
\hline
\end{tabular}

a (I), following diagnosis; $(\mathrm{R})$, during remission

secretory defects [11]. This association was evidenced, with a predominance of insulin secretory defect in metabolic studies of atypical diabetes $[1,2,9]$. Predominant insulin secretory defect is known to be a feature of Type II diabetes in populations of African ancestry $[14,15]$.

The disturbing feature would therefore be ketosis that develops at diagnosis or during relapses without known precipitating factors such as infection or trauma. Ketosis is an exceptional finding in classic Type II diabetes, unless there is a specific cause [12]. Of interest, ketosis does not automatically reappear after withdrawal of insulin treatment. Patients only require insulin for a limited period of time. Insulin secretion in response to glucose that is partially defective could be impaired in addition by glucose and/or lipotoxicity. Moreover, glucagon, the main ketogenic hormone in humans is increased in Type II diabetes and a relative hyperglucagonaemia was also evidenced in African-American children with acute-onset Type II diabetes [16]. We therefore hypothesise that this atypical diabetes is a subtype of Type II diabetes, which develops in patients with high sensitivity to glucotoxicity or lipotoxicity, or with dysregulation of glucagon secretion.

Paediatricians now recognise Type II diabetes in children, predominantly in obese African-Americans. The presentation is in many points similar to that of ketosis-prone atypical diabetes of adults with initial manifestations of insulinopaenia and the subsequent course of Type II diabetes [17].

Further identification of molecular mechanisms of this atypical form of diabetes might lead to its recognition as "Type III" or its classification under "other specific types". Additional pathophysiological insight is therefore needed to provide a better understanding of the mechanisms of the partially reversible insulin secretory defect in atypical diabetes. Nevertheless, to date, there is more clinical and metabolic evidence to support the classification of this entity as ketosisprone Type II diabetes rather than idiopathic Type I diabetes in adults. Indeed, Type II diabetes is defined as those types of diabetes that are not Type I and for which there is no known cause [12].

\section{References}

1. Banerji MA, Chaiken RL, Huey H et al. (1994) GAD antibody negative NIDDM in adult black subjects with diabetic ketoacidosis and increased frequency of human leukocyte antigen DR3 and DR4. Flatbush diabetes. Diabetes 43: 741-745

2. Umpierrez GE, Casals MM, Gebhart SP, Mixon PS, Clark WS, Phillips LS (1995) Diabetic ketoacidosis in obese African-Americans. Diabetes 44: 790-795

3. Oli JM (1978) Remittant diabetes mellitus in Nigeria. Trop Geogr Med 30: 57-62

4. Oli JM, Bottazzo GF, Doniach D (1981) Islet cell antibodies and diabetes in Nigerians. Trop Geogr Med 33: 161-164

5. Ahren B, Corrigan CB (1985) Intermittent need for insulin in a subgroup of diabetic patients in Tanzania. Diabet Med 2: $262-264$

6. Dodu SR (1967) Diabetes in the tropics. BMJ 2: 747-750

7. Yamada K, Nonaka K (1996) Diabetic ketoacidosis in young obese Japanese men. Diabetes Care 19: 671

8. Umpierrez GE, Woo W, Hagopian WA et al. (1999) Immunogenetic analysis suggests different pathogenesis for obese and lean African-Americans with diabetic ketoacidosis. Diabetes Care 22: 1517-1523 
9. Sobngwi E, Sardinha E, Lepage V, Vexiau P, Cathelineau G, Gautier JF (2000) Immunologic and HLA markers do not predict long term insulin therapy in adult black Africans with diabetes. EASD annual meeting, Jerusalem, 2000. Diabetologia 43[Suppl 1]: A181 (Abstract)

10. Banerji MA, Chaiken RL, Lebovitz HE (1996) Long-term normoglycemic remission in black newly diagnosed NIDDM subjects. Diabetes 45: 337-341

11. Report of the Expert Committee on the Diagnosis and Classification of Diabetes Mellitus (1997) Diabetes Care 20: 1183-1197

12. Alberti KG, Zimmet PZ (1998) Definition, diagnosis and classification of diabetes mellitus and its complications. Part 1: diagnosis and classification of diabetes mellitus provisional report of a WHO consultation. Diabet Med 15: 539-553
13. King H, Aubert RE, Herman WH (1998) Global burden of diabetes, 1995-2025: prevalence, numerical estimates, and projections. Diabetes Care 21: 1414-1431

14. UK Prospective Diabetes Study (1994) XII: Differences between Asian, Afro-Caribbean and white Caucasian type 2 diabetic patients at diagnosis of diabetes. UK Prospective Diabetes Study Group. Diabet Med 11: 670-677

15. Joffe BI, Seftel HC (1994) Diabetes mellitus in the black communities of southern Africa. J Intern Med 235: 137-142

16. Umpaichitra V, Bastian W, Taha D, Banerji MA, AvRuskin TW, Castells S (2001) C-peptide and glucagon profiles in minority children with type 2 diabetes mellitus. J Clin Endocrinol Metab 86: 1605-1609

17. Pinhas-Hamiel O, Dolan LM, Zeitler PS (1997) Diabetic ketoacidosis among obese African-American adolescents with NIDDM. Diabetes Care 20: 484-486 